\title{
Paideusis
}

\section{In Memory: Kenneth Farnam Argue 1906-1994}

\section{Sandra Bruneau}

Volume 8, Number 1, 1994

URI: https://id.erudit.org/iderudit/1073260ar

DOI: https://doi.org/10.7202/1073260ar

See table of contents

Publisher(s)

Canadian Philosophy of Education Society

ISSN

0838-4517 (print)

1916-0348 (digital)

Explore this journal

Cite this document

Bruneau, S. (1994). In Memory: Kenneth Farnam Argue 1906-1994. Paideusis, 8(1), 3-4. https://doi.org/10.7202/1073260ar

This document is protected by copyright law. Use of the services of Erudit (including reproduction) is subject to its terms and conditions, which can be viewed online.

https://apropos.erudit.org/en/users/policy-on-use/
This article is disseminated and preserved by Érudit.

Érudit is a non-profit inter-university consortium of the Université de Montréal, Université Laval, and the Université du Québec à Montréal. Its mission is to promote and disseminate research.

https://www.erudit.org/en/ 


\section{In Memory}

\section{Kenneth Farnam Argue \\ 1906-1994}

Kenneth Argue died in Vancouver on June 2, 1994. "Ken" was a pioneer builder in Canadian philosophy of education. Born in Vegreville, Alberta, he was educated at the University of Alberta (B.A. Hons., 1931), Oxford University (M.A., P.P.E. course, 1936, in part under John Maynard Keynes), and Columbia University (D.Ed., 1940). His stint at Columbia placed him squarely in a longstanding Canadian tradition. Before he arrived, that university had welcomed H.T.J. Coleman of Queen's University and University of British Columbia (UBC), J.H. Putman of Ottawa, and G.J. Langley of the University of Saskatchewan-all of them writers of innumerable articles, books, and reports on what might be called "the social aspects" of curricular and administrative policy. Ken's well-informed pragmatism, formed from close association with John Dewey, was wholly consistent with the views of his predecessors, and served him well in a highly productive career as teacher, administrator, and writer on educational policy.

After a dozen years teaching in Alberta schools, Ken spent 1939 and 1940 doing research for the state of New York in Albany and in St. Louis, Missouri. He married Jean Irwin in 1943. Ken became a professor of education at the University of Alberta (1940-6) and at the University of British Columbia (1946-72). Between 1940 and 1950, his writings were almost entirely concerned with applications of distributive theory in educational finance. His analyses of finance and educational opportunity were conjoined with a frankly Deweyan outlook on matters of social justice. Ken's reports on state funding of education in Canada and Newfoundland (James Commission, 1942-3) complemented those of Leonard Marsh on broad social policy and helped to build the post-war consensus on universal educational provision.

After 1950, Ken's view of philosophy was increasingly driven by the requirements of the classroom and the profession and by forms of argument drawn from his first field of study-history. His textbook on the history of educational theory (The Development of Education Theory, Vancouver: UBC, 1951) sees philosophy as the study of "motivating principles in educational administration and practice." Another instance is his paper, "Some thoughts concerning the role of the educator in today's educational controversy" (Thought, 1960), which appeared in the year of publication of the Chant Royal Commission on Education in British Columbia and gave moral and historical reasons why philosophers should participate in educational politics.

Throughout the 1950s and 1960s, Ken gave courses in Vancouver and elsewhere, built and rebuilt UBC's B.Ed. curriculum (always giving pride of place to philosophical and historical studies), and for ten consecutive years headed the UBC Summer School. In 1966, he was the first chairperson of the Department of Educational Foundations. He was a participant in (and at one point chair of) a vast revision of the British Columbia Social Studies curriculum in the 1960s. 
Ken's public service included consulting on a number of commissions and representing UBC at two World Congresses of the Teaching Profession-Stockholm in 1962 and Dublin in 1968.

Beyond these contributions to the teaching profession, Ken helped to found and maintain the Canadian Association of Professors of Education (CAPE). At his retirement, CAPE participated in forming the Canadian Society for the Study of Education (CSSE), an outcome for which he had worked over several years. Apart from his extensive activity in professional matters, Ken maintained his "English connection" through memberships in the Royal Institute of Philosophy and the Aristotelian Society, not to overlook his fellowships in the Philosophy of Education Societies of Great Britain and the United States.

Ken's enthusiasm and kindness were infectious, as generations of undergraduates, graduates, and junior professors will attest. Those characteristics are all too rare among us. In his life and work, they were embodied in this Canadian progressive's social and political theories. Ken was well suited to the task of reconstructing education-and society. He was the right man in the right place at the right time.

We shall miss the energy, the sense of moral engagement, the philosophical wit, and the unexpectedly droll good humour of Ken Argue.

Ken is survived by Jean, two children, Corinne and Richard, and by three grandsons, Martin and David Sanderson, and Geoffrey Argue.

Sandra Bruneau, University of British Columbia 